AGRICULTURE AND BIOLOGY JOURNAL OF NORTH AMERICA

ISSN Print: 2151-7517, ISSN Online: 2151-7525, doi:10.5251/abjna.2012.3.1.17.24

(C) 2012, ScienceHu $\beta$, http://www.scihub.org/ABJNA

\title{
Effect of four different tillage practices on soil physical properties under cowpea
}

\author{
'S.H.M. Aikins and ${ }^{2}$ J.J. Afuakwa \\ ${ }^{1}$ Department of Agricultural Engineering, College of Engineering, \\ Kwame Nkrumah University of Science \& Technology, Kumasi, Ghana. \\ Email: stevenaikins@yahoo.com; shmaikins.coe@knust.edu.gh \\ ${ }^{2}$ Department of Agroforestry, College of Agriculture and Natural Resources, \\ Kwame Nkrumah University of Science and Technology, Kumasi, Ghana.
}

\begin{abstract}
Cowpea (Vigna unguiculata [L.] Walp) is grown by resource poor farmers in Ghana using different tillage practices. Most of these farmers perform tillage operations without being aware of the effect of these operations on soil physical properties and crop responses. A field study was conducted during the 2009 and 2010 major crop growing seasons under rainfed conditions on sandy loam soil (Ferric Acrisol) to compare the effect of different tillage practices on some selected soil physical properties under Asontem cowpea variety. The experiment was arranged in a randomized complete block design with three replications. The treatments consisted of disc ploughing only, disc ploughing followed by disc harrowing, disc harrowing only and no tillage. Compared with the other treatments, the disc ploughing followed by disc harrowing treatment gave the most favourable soil conditions (i.e. lowest soil penetration resistance, lowest dry bulk density, highest soil moisture content, and highest total porosity). The no tillage plots produced the most unfavourable soil conditions (i.e. highest soil penetration resistance, highest dry bulk density, lowest soil moisture content, and lowest total porosity). Therefore, under the soil and weather conditions of the experiment, the best tillage practice identified for Asontem cowpea production is disc ploughing followed by disc harrowing.
\end{abstract}

Keywords: Cowpea, tillage, soil, soil physical properties.

\section{INTRODUCTION}

Cowpea (Vigna unguiculata (L) Walp) is a very important grain legume crop which provides food security and employment to many farmers in Ghana. In Ghana, cowpea is produced largely by resource poor farmers under rainfed condiotions. These farmers employ different tillage practices in the production of the crop. While some farmers sow cowpea after disc ploughing without disc harrowing, other farmers disc plough and disc harrow before sowing. There are some farmers who disc harrow without disc ploughing before sowing while others use no tillage in the production of cowpea (Aikins and Afuakwa, 2010). Many farmers perform tillage operations without being aware of the effect of these operations on soil physical properties and crop responses (Ozpinar and Isik, 2004). Tillage is a management input that affects soil physical characteristics (Hamblin, 1985) cited by (Katsvairo et al., 2002). Soil physical properties are important for favourable conditions for crop growth and maintaining soil quality (Rachman et al., 2003). The suitability of a soil for sustaining plant growth and biological activity is a function of physical and chemical properties (Mulumba and Lal, 2008).

Soil is a key natural resource and soil quality is the integrated effect of management on most soil properties that determine crop productivity and sustainability (Anikwe and Ubochi, 2007; Franzluebbers, 2002). Tillage practices profoundly affect soil physical properties. It is essential to select a tillage practice that sustains the soil physical properties required for successful growth of agricultural crops (Jabro et al., 2009). Seedbed preparation is crucial for crop establishment, growth and ultimately yield (Atkinson et al., 2007). Tillage systems create an ideal seedbed condition for plant emergence, development, and unimpeded root growth (Licht and Al-Kaisi, 2005). 
Tillage is expected to influence soil physical properties. However, the changes in soil properties differ among management practices (Elder and Lal, 2008). Information is needed on the effect of tillage practice on soil physical properties under cowpea in the semi deciduous rain forest agro-ecological zone of Ghana. The objective of the study was to compare the effect of different tillage practices on soil penetration resistance, dry bulk density, moisture content, and total porosity.

\section{MATERIALS AND METHODS}

Study Site Description: The study area was located at the Plantation Section field of the Department of Crop and Soil Sciences in the Faculty of Agriculture, Kwame Nkrumah University of Science and Technology, Kumasi, Ghana (latitude $6^{\circ} 41^{\prime} 0 " \mathrm{~N}$, longitude $1^{\circ} 33^{\prime} 3^{\prime \prime} \mathrm{W}$ and altitude $296.6 \mathrm{~m}$ above sea level). The experiments were conducted during the 2009 and 2010 major crop growing seasons. The average daily temperature in the study area is about $26^{\circ} \mathrm{C}$ with a range between 18 and $35^{\circ} \mathrm{C}$. The same field was used for the experiment in 2009 as well as in 2010 . The study area had been previously sown to groundnut (Arachis hypogea, L.) for two years and maize (Zea mays, L.) for one year prior to starting the experiment. The average annual rainfall is $1300 \mathrm{~mm}$. The experimental plots were located on a well drained sandy loam soil. The soil is classified as Ferric Acrisol (Adu, 1992; FAO, 1998) (Paleustult in USDA Classification). Details of selected physical and chemical characteristics of the soil at the experimental site are reported in Table 1.

Table 1: Selected Soil Physical and Chemical Properties at the Experimental Site

\begin{tabular}{|l|c|c|}
\hline \multirow{2}{*}{ Soil Property } & \multicolumn{2}{|c|}{ Soil layer (cm) } \\
\cline { 2 - 3 } & $0-15$ & $15-30$ \\
\hline Sand (\%) & 71.84 & 85.60 \\
\hline Silt (\%) & 26.15 & 6.40 \\
\hline Clay (\%) & 2.01 & 8.00 \\
\hline Organic Carbon (\%) & 0.78 & 0.76 \\
\hline Organic Matter (\%) & 1.34 & 1.31 \\
\hline $\mathrm{pH}$ & 5.6 & 5.2 \\
\hline Total N (\%) & 0.07 & 0.04 \\
\hline Ca $\left(\mathrm{cmol} \mathrm{kg}^{-1}\right)$ & 1.60 & 1.87 \\
\hline $\mathrm{Mg}\left(\mathrm{cmol} \mathrm{kg}^{-1}\right)$ & 1.07 & 0.27 \\
\hline $\mathrm{K}\left(\mathrm{cmol} \mathrm{kg}^{-1}\right)$ & 0.19 & 0.17 \\
\hline$N H_{4}^{+} N\left(\mathrm{cmol} \mathrm{kg}^{-1}\right)$ & 1.56 & 0.31 \\
\hline Available P $\left(\mathrm{cmol} \mathrm{kg}^{-1}\right)$ & 22.64 & 16.90 \\
\hline $\mathrm{Na}\left(\mathrm{cmol} \mathrm{kg}^{-1}\right)$ & 0.03 & 0.04 \\
\hline
\end{tabular}

Experimental Design: The experiment was arranged in a randomised complete block design with four tillage treatments consisting of disc ploughing only, disc ploughing followed by disc harrowing, disc harrowing only and no tillage replicated three times. Each plot size was $2.4 \mathrm{~m} \times 2.4 \mathrm{~m}$ with a buffer zone of $1.5 \mathrm{~m}$ between plots. Tillage operations were carried out using a $35.3 \mathrm{~kW}$ Shanghai tractor. Ploughing was done with a 3 -Disc plough while harrowing was done with an offset harrow.

Crop Management Practices: Details of crop management practices used for the experiment including sowing, weed control, insect pest control and harvesting have been reported by Aikins and Afuakwa (2010).

\section{Data Collection}

Penetration Resistance: Soil penetration resistance measurements were made using a pocket penetrometer. Ten soil penetration resistance measurements were randomly taken per plot once a week for eight weeks and after harvest. The first set of readings was taken on the day sowing was done. The measurement were first taken in $\mathrm{kg} \mathrm{cm}^{-2}$ and later converted to $\mathrm{kPal}$.

Dry Bulk Density: Soil dry bulk density in the 0-10 $\mathrm{cm}$ and $10-20 \mathrm{~cm}$ layers were determined using the core method. Three soil samples were randomly taken per plot once a week for eight weeks and after harvest using a stainless steel core sampler of dimension $5 \mathrm{~cm}$ diameter by $5 \mathrm{~cm}$ height. The collected soil cores were trimmed to the exact volume of the cylinder and oven dried at $105{ }^{\circ} \mathrm{C}$ for 24 hours. Precautions were taken to avoid compaction inside the core sampler. Dry bulk density was determined from the ratio of mass of dry soil per unit volume of soil cores.

Moisture Content: Three soil samples were taken at random locations in each plot from the $0-10 \mathrm{~cm}$ and $10-20 \mathrm{~cm}$ soil layers with a soil core sampler $5 \mathrm{~cm}$ long and $5 \mathrm{~cm}$ in diameter on a weekly basis for eight weeks and after harvest. Samples were oven-dried at $105^{\circ} \mathrm{C}$ for 24 hours to determine the soil moisture content gravimetrically (ASABE Standards, 2008). The gravimetric moisture content was calculated as the mass of moisture in the soil sample divided by the mass of the dry soil multiplied by 100 .

Total Porosity: The total porosity of the soil in the 0 $10 \mathrm{~cm}$ and $10-20 \mathrm{~cm}$ layers were calculated from the values of the dry bulk density and an assumed particle density of $2.65 \mathrm{Mg} \mathrm{m}^{-3}$ using the following Equation (Chancellor, 1994). The result was multiplied by 100 : 
Total Porosity $(\%)=\left(1-\frac{\rho_{b}}{\rho_{p}}\right) \times 100$

where

$\rho_{b}=$ Dry bulk density $\left(\mathrm{Mg} \mathrm{m}^{-3}\right)$

$\rho_{p}=$ Particle density $\left(\mathrm{Mg} \mathrm{m}^{-3}\right)$

Data Analyses: Statistical data analyses were performed on all data collected using the Balanced Analysis of Variance (ANOVA) Model in MINITAB Statistical Software Release 15 (MINITAB Inc., 2007). The mean values of soil penetration resistance, dry bulk density, moisture content and porosity were compared on treatment basis using the least significant difference test at $p<0.05$.

\section{RESULTS AND DISCUSSION}

Effect of Tillage Practice on Soil Penetration Resistance: Penetrometer resistance measurements of soil can be used to assess the need for tillage operations, which help maintain effective plant rooting and facilitate good water and nutrient uptake (Veenstra et al., 2006). Fig. 1 and Fig. 2 show the effect of the different tillage practices on soil penetration resistance. Tillage practice significantly affected soil penetration resistance over the period of the experiment. Among the tillage practices, soil penetration resistance was significantly higher under No Tillage as compared with that in the tilled soil treatments. In 2009 the highest soil penetration resistance value of $661 \mathrm{kPa}$ was found in the No Tillage plots while the lowest soil penetration resistance value of $117 \mathrm{kPa}$ was recorded in the disc ploughing followed by disc harrowing plots. In 2010, soil penetration resistance ranged from $559 \mathrm{kPa}$ under No Tillage to $118 \mathrm{kPa}$ under disc ploughing followed by disc harrowing treatment. Similarly, Olaoye (2002) reported higher soil penetration resistance in the No Tillage treatment in comparison with the disc ploughing followed by disc harrowing treatment for Ferric Luvisol in the rain forest zone of Akure in Nigeria. In 2009, penetration resistance under the disc harrowing only treatment was lower than that of the disc ploughing only treatment. In 2010, penetration resistance under the disc ploughing only treatment was lower than that of the disc harrowing only treatment. Disc ploughing followed by disc harrowing plots which produced the lowest soil penetration resistance gave the best Asontem cowpea performance. On the other hand, the No Tillage plots which had the highest penetration resistance values were associated with the poorest Asontem cowpea performance (Aikins and Afuakwa, 2010). Penetration resistance measures the energy that must be exerted by the young seedling to emerge from the soil. It indicates resistance that must be overcome by the young rootlets in their search for nutrients and water in the soil (Olaoye, 2002).

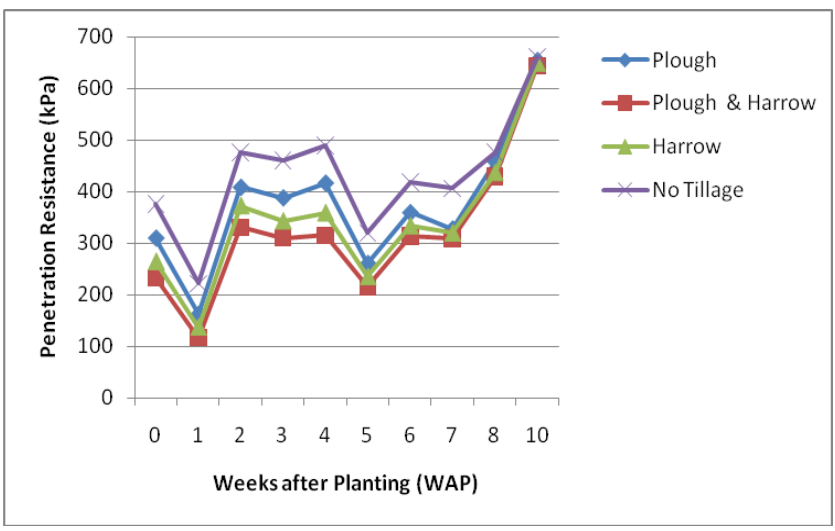

Fig. 1: Effect of Tillage Practice on Soil Penetration Resistance (2009)

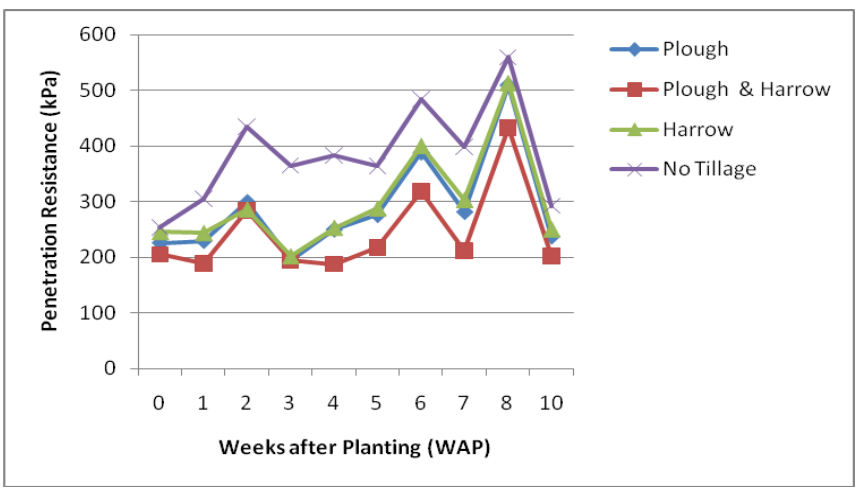

Fig. 2: Effect of Tillage Practice on Soil Penetration Resistance (2010)

Effect of Tillage Practice on Dry Bulk Density: Soil bulk density is probably the most frequently measured soil quality parameter in tillage experiments (Rasmussen, 1999). The effect of the different tillage practices on dry bulk density in the 0 $10 \mathrm{~cm}$ and $10-20 \mathrm{~cm}$ layers are depicted in Fig. 3, Fig. 4, Fig. 5 and Fig. 6 respectively. Over the course of the study, tillage practices significantly affected soil dry bulk density. The No Tillage treatment recorded the highest dry bulk density significantly higher than that of the disc ploughing followed by disc harrowing 
treatment, which produced the lowest dry bulk density. In 2009, soil dry bulk density recorded in the $0-10 \mathrm{~cm}$ layer ranged from $1.47 \mathrm{Mg} \mathrm{m}^{-3}$ to $1.54 \mathrm{Mg}$ $\mathrm{m}^{-3}$ for the No Tillage treatment, and from $1.39 \mathrm{Mg} \mathrm{m}^{-}$ ${ }^{3}$ to $1.47 \mathrm{Mg} \mathrm{m}^{-3}$ for the disc ploughing followed by disc harrowing treatment. Similarly, soil dry bulk density in the 10-20 cm layer, ranged from $1.49 \mathrm{Mg}$ $\mathrm{m}^{-3}$ to $1.55 \mathrm{Mg} \mathrm{m}^{-3}$ for the No Tillage treatment and from $1.39 \mathrm{Mg} \mathrm{m}^{-3}$ to $1.46 \mathrm{Mg} \mathrm{m}^{-3}$ for disc ploughing followed by disc harrowing treatment. In 2010, soil dry bulk density recorded in the $0-10 \mathrm{~cm}$ layer ranged from $1.33 \mathrm{Mg} \mathrm{m}^{-3}$ to $1.45 \mathrm{Mg} \mathrm{m}^{-3}$ for No Tillage, and from $1.20 \mathrm{Mg} \mathrm{m}^{-3}$ to $1.32 \mathrm{Mg} \mathrm{m}^{-3}$ for the disc ploughing followed by disc harrowing treatment. Similarly, soil dry bulk density in the $10-20 \mathrm{~cm}$ layer, ranged from $1.38 \mathrm{Mg} \mathrm{m}^{-3}$ to $1.46 \mathrm{Mg} \mathrm{m}^{-3}$ for the No Tillage treatment and from $1.21 \mathrm{Mg} \mathrm{m}^{-3}$ to $1.34 \mathrm{Mg} \mathrm{m}^{-1}$ ${ }^{3}$ for the disc ploughing followed by disc harrowing treatment. The lowest dry bulk densities found in the disc ploughing followed by disc harrowing plots are supported by the best cowpea performance. Conversely, the highest soil dry bulk densities observed in the No Tillage plots are supported by the worst cowpea performance (Aikins, and Afuakwa, 2010).

Overall, these findings widely agree with results found by (Kombiok et al., 2005) working under Ferric Luvisol in the northern Guinea savannah zone of Ghana. Ojeniyi and Adekayode (1999) working under Ferric Luvisol in the rainforest zone at Akure in Nigeria also reported similar results. On the other hand, Olaoye (2002) found higher dry bulk density in disc ploughing followed by disc harrowing plots compared with that of the No Tillage plots for Ferric Luvisol in the rainforest zone at Akure, Nigeria.

The bulk density of a soil gives an indication of the soil's strength and thus resistance to tillage implements or plants as they penetrate the soil. Soils with higher proportion of pores to solids have lower bulk densities than those that are compact and have fewer pores (Brady and Weil, 1999.). Bulk densities in excess of $1.6 \mathrm{Mg} \mathrm{m}^{-3}$ can restrict root growth and result in low levels of water movement into and within the soil (Smith, 1988).

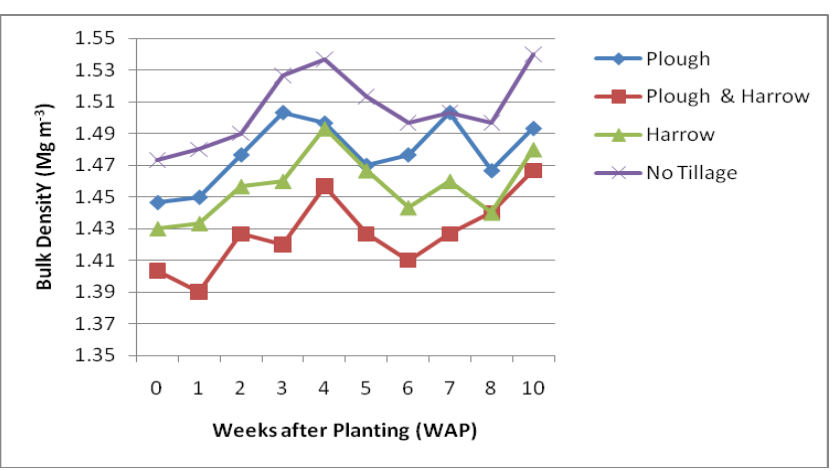

Fig. 3: Effect of Tillage Practice on Dry Bulk Density: 0$10 \mathrm{~cm}$ (2009)

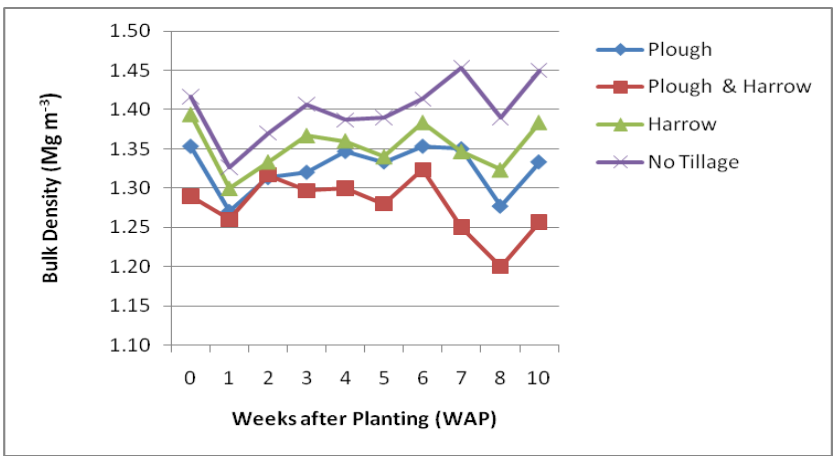

Fig. 4: Effect of Tillage Practice on Dry Bulk Density: 0$10 \mathrm{~cm}(2010)$

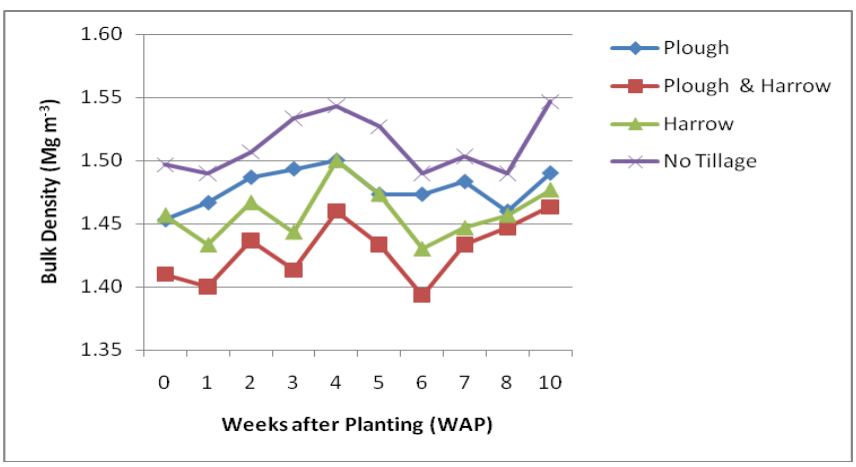

Fig. 5: Effect of Tillage Practice on Dry Bulk Density: 10-20 cm (2009) 


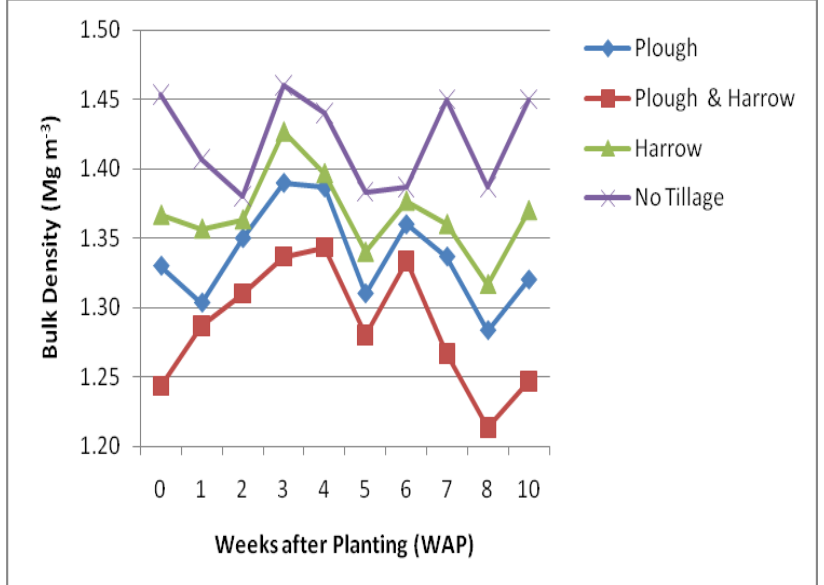

Fig. 6: Effect of Tillage Practice on Dry Bulk Density: 10-20 cm (2010)

Effect of Tillage Practice on Moisture Content: Soil moisture is the source of water for plant use in particular in rainfed agriculture (Mweso, 2003). Soil moisture is highly critical in ensuring good and uniform seed germination and seedling emergence (Arsyid et al., 2009), crop growth and yield. Fig. 7, Fig. 8, Fig. 9 and Fig. 10 depict the mean soil moisture content values obtained under the different tillage practices over the course of the study in the 0 $10 \mathrm{~cm}$ and $10-20 \mathrm{~cm}$ soil layers respectively. In the 0-10 cm soil layer for the 2009 major growing season, tillage treatments showed significant influence in moisture content from the planting date through the first five weeks after planting, and after harvest. There was no significant difference in moisture content from the sixth to the eighth week after planting in the $0-10 \mathrm{~cm}$ soil layer. In the $0-10$ $\mathrm{cm}$ soil layer for the 2010 major growing season, tillage treatments significantly affected moisture content only on the planting date, the seventh and eight week after planting, and after harvest. Tillage treatment caused significant difference in moisture content in the 10-20 cm soil layer throughout the 2009 major growing season except at seven and eight weeks after planting. Tillage treatment did not significantly influence soil moisture content in the 10$20 \mathrm{~cm}$ soil layer from the planting date through the first five weeks after planting during the 2010 major growing season. Significant differences in soil moisture content were observed at six, seven and eight weeks after planting, and after harvest.

Plots with disc ploughing followed by disc harrowing tillage had the highest soil moisture contents. The lowest soil moisture contents were located in the No Tillage plots. In contrast, Ojeniyi and Adekayode
(1999) and Olaoye (2002) found higher soil moisture content in No Tillage plots compared with that of disc ploughed followed by disc harrowed plots. The highest moisture content values in the disc ploughing followed by disc harrowing treatment were associated with the best Asontem cowpea performance. On the other hand the lowest moisture content values in the No Tillage plots were associated with the worst Asontem cowpea performance (Aikins and Afuakwa, 2010). Differences in the trend in soil moisture content between 2009 and 2010 may be attributed to the weather. Rainfall amount for March, 2009 was $162.9 \mathrm{~mm}$ while that for March, 2010 was $41.3 \mathrm{~mm}$. Rainfall amount for May, 2009 was $99.0 \mathrm{~mm}$ while that for May, 2010 was $132.6 \mathrm{~mm}$ (Aikins and Afuakwa, 2010).

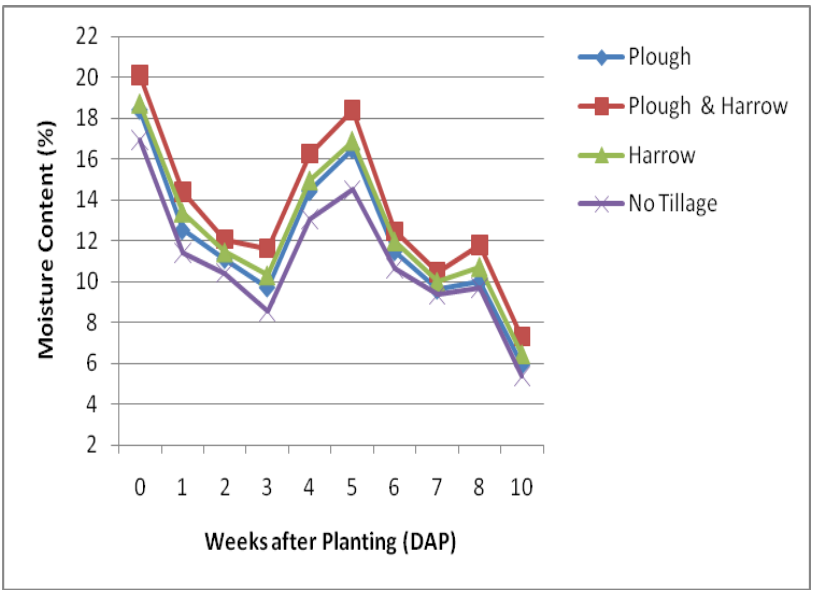

Fig. 7: Effect of Tillage Practice on Moisture Content: 0-10 cm (2009)

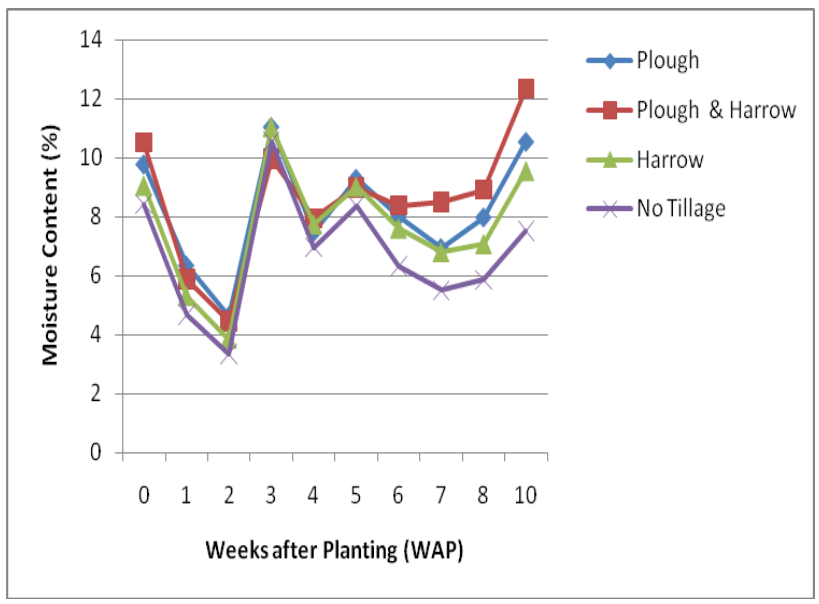

Fig. 8: Effect of Tillage Practice on Moisture Content: 0-10 cm (2010) 


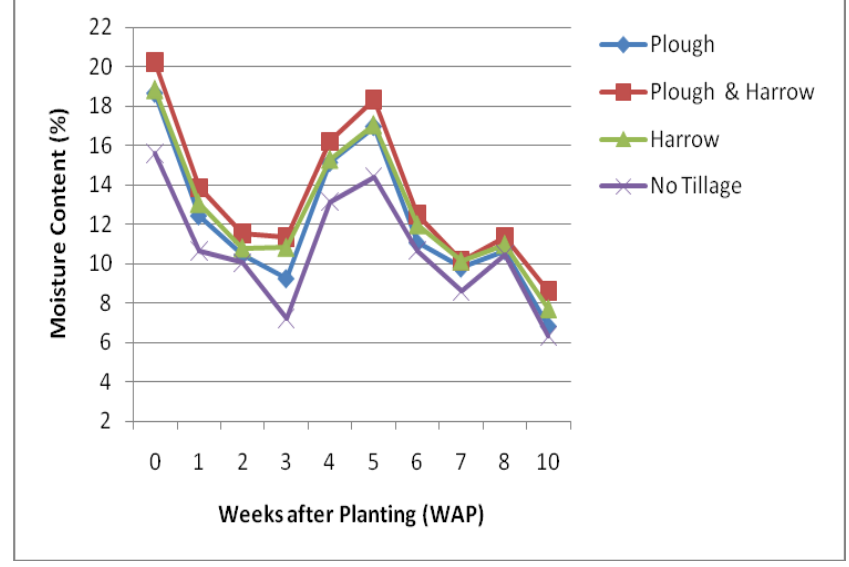

Fig. 9: Effect of Tillage Practice on Moisture Content: $10-20 \mathrm{~cm}$ (2009)

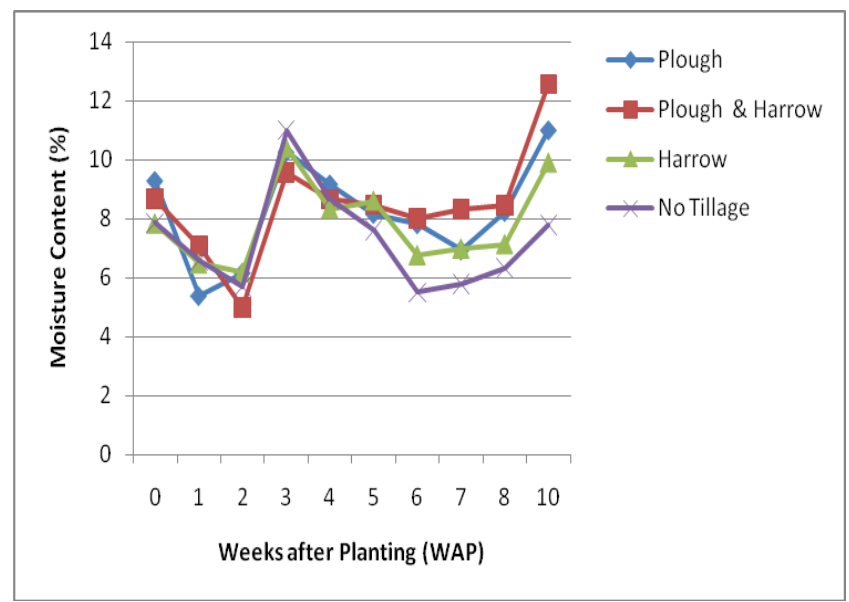

Fig. 10: Effect of Tillage Practice on Moisture Content: 10-20 cm (2010)

Effect of Tillage Practice on Total Porosity: Soil porosity and organic matter content play a critical role in the biological productivity and hydrology of agricultural soils. Pores are of different size, shape and continuity and these characteristics influence the infiltration, storage and drainage of water, the movement and distribution of gases, and the ease of penetration of soil by growing roots (Kay and VandenBygaart, 2002.). The mean total porosity obtained in the $0-10 \mathrm{~cm}$ and $10-20 \mathrm{~cm}$ soil layers under the four different tillage treatments over the field experiment period are presented in Fig. 11, Fig. 12, Fig. 13 and Fig. 14. Tillage practices significantly affected soil porosity for both the $0-10 \mathrm{~cm}$ and $10-20$ $\mathrm{cm}$ soil layers. Overall, in both the $0-10 \mathrm{~cm}$ and $10-$ $20 \mathrm{~cm}$ soil layers, the disc ploughing followed by disc harrowing treatment produced the highest total porosity while the No Tillage treatment gave lowest total porosity. Elder and Lal (2008) also reported higher total porosity in the tilled plots compared with the No Tillage plots for organic soils of north central Ohio.

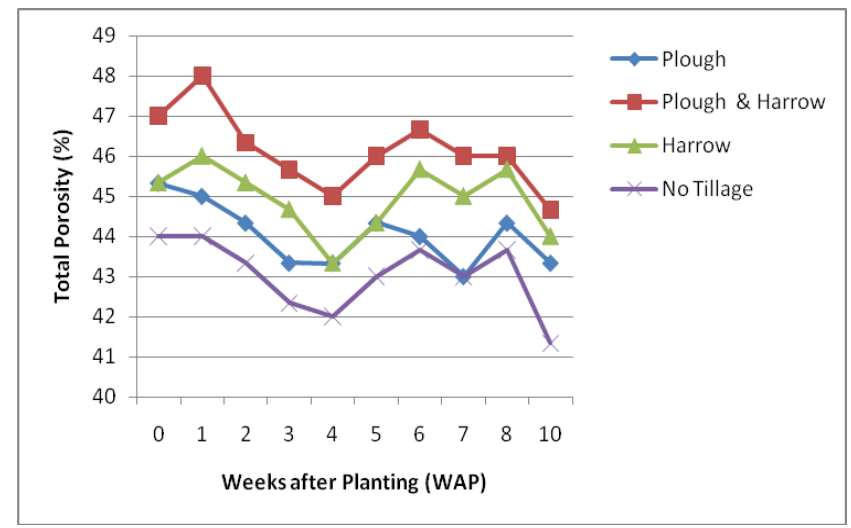

Fig. 11: Effect of Tillage Practice on Total Porosity: 0$10 \mathrm{~cm}$ (2009)

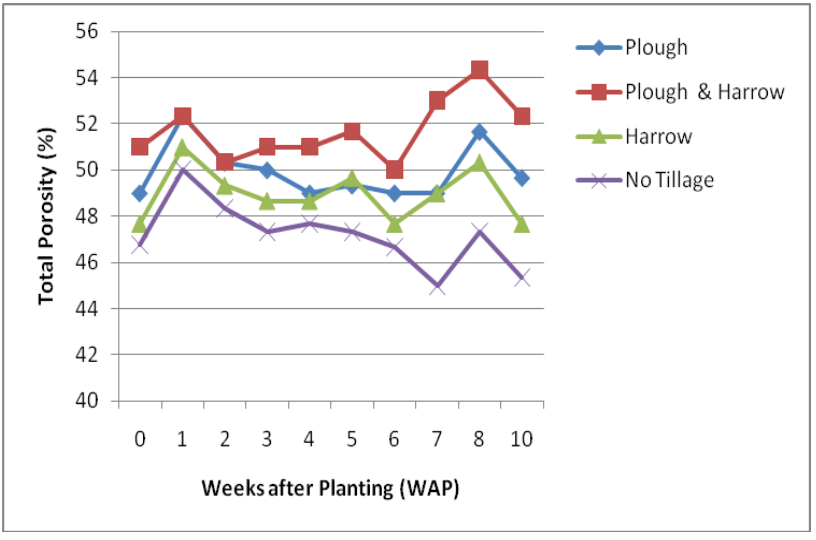

Fig. 12: Effect of Tillage Practice on Total Porosity: 0$10 \mathrm{~cm}(2010)$

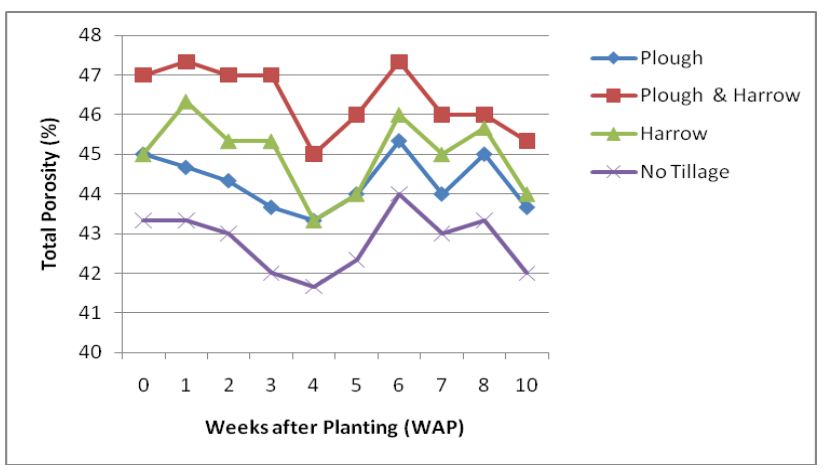

Fig. 13: Effect of Tillage Practice on Total Porosity: 10$20 \mathrm{~cm}$ (2009) 


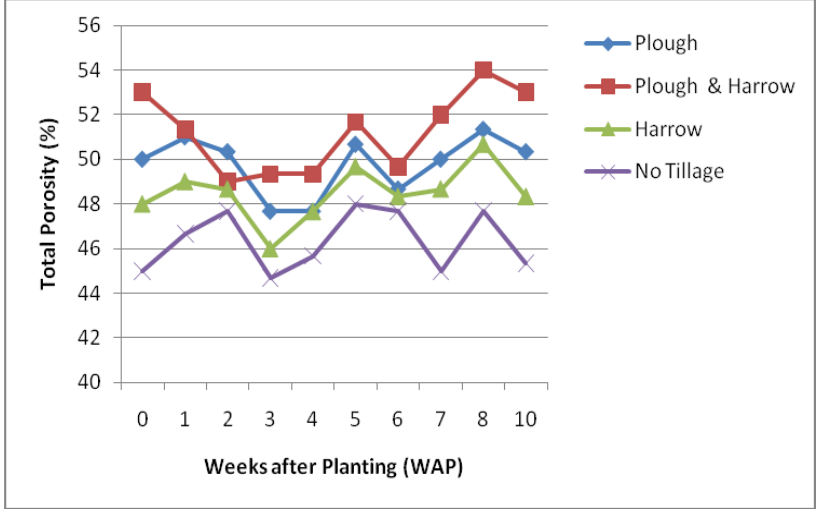

Fig. 14: Effect of Tillage Practice on Total Porosity: 10 $20 \mathrm{~cm}$ (2010)

\section{CONCLUSION}

From the results, the following can be concluded: Tillage treatments significantly affected soil penetration resistance, dry bulk density, moisture content and total porosity. The disc ploughing followed by disc harrowing treatment presented the lowest soil penetration resistance and dry bulk density, and the highest moisture content and total porosity. The no tillage treatment produced the highest soil penetration resistance and dry bulk density, and the lowest moisture content and total porosity. Under the soil and weather conditions of the experiment, the results indicate that the best tillage treatment for the production of Asontem cowpea variety is the disc ploughing followed by disc harrowing.

\section{ACKNOWLEDGEMENT}

The authors wish to thank Crops Research Institute (CRI) of the Council for Scientific and Industrial Research (CSIR) for kindly providing Asontem cowpea variety seeds for the experiment. Sincere thanks also go to Messrs R. Opoku and D.A. Pappoe for assisting with field operations and data collection.

\section{REFERENCES}

Adu, S.V. (1992). Soils of the Kumasi Region, Ashanti Region, Ghana. Memoir No. 8. CSIR-Soil Research Institute, Kwadaso, Kumasi.

Aikins, S.H.M. and Afuakwa, J.J. (2010). Effect of Four Different Tillage Practices on Cowpea Performance, World Journal of Agricultural Sciences, 6 (6): 644-651.

Anikwe, M.A.N. and Ubochi, J.N. (2007). Short-term changes in soil properties under tillage systems and their effect on sweet potato (Ipomea batatas L.) growth and yield in an Ultisol in south-eastern Nigeria, Australian Journal of Soil Research, 45, 351-358.
Arsyid, M.A, Camacho, F.T. and Guo, P. (2009). Corn Basics: Corn Crop Management, Available Online: http://www.dekalb-

asia.com/pdf/CB2_CornCropManagement.pdf

ASABE Standards (2008). ASAE S358.2 DEC1988 (R2008): Moisture Measurement - Forages. ASABE St. Joseph, Michigan.

Atkinson, B.S., Sparkes, D.L. and Mooney, S.J. (2007). Using selected soil physical properties of seedbeds to predict crop establishment, Soil \& Tillage Research, 97 (2): 218-228.

Brady, N.C. and Weil, R.R. (1999). The Nature and Properties of Soils, $\left(12^{\text {th }}\right.$ edn.), Prentice Hall, Inc, New Jersey.

Chancellor, W.J. (1994). Advances in Soil Dynamics: Volume 1, Chapter 2, ASAE, St. Joseph, Michigan.

Elder, J.W. and Lal, R. (2008). Tillage effects on physical properties of agricultural organic soils of north central Ohio, Soil \& Tillage Research, 98 (2): 208-210.

FAO (1998). World reference base for soil resources. World Soil Resources Report 84, Food and Agriculture Organization of the United Nations, Rome.

Franzluebbers A.J. (2002). Soil organic matter stratification ratio as an indicator of soil quality, Soil \& Tillage Research, 66 (2): 95-106.

Hamblin, A.P. (1985). The influence of soil structure on water movement, crop root growth, and water uptake. Adv. Agron. 38:95-158.

Jabro, J.D., Stevens, W.B., Evans, R.G. and Iversen, W.M. (2009). Tillage effects on physical properties in two soils of the Northern Great Plains, Applied Engineering in Agriculture, 25 (3): 377-382.

Katsvairo, T., Cox, W.J. and van Es, H. (2002). Tillage and Rotation Effects on Soil Physical Characteristics, Agron. J., 94:299-304.

Kay, B.D. and VandenBygaart, A.J. (2002). Conservation tillage and depth stratification of porosity and soil organic matter, Soil \& Tillage Research, 66 (2): 107118.

Kombiok, J.M., Safo, E.Y. and Quansah, C. (2005). Yield and Nitrogen Fixation of Cowpea as affected by tillage and Cropping Systems in the Northern Savanna Zone of Ghana, West African J. Appl. Ecol., 7: 95-108.

Licht, M.A. and Al-Kaisi, M. (2005). Strip-tillage effect on seedbed soil temperature and other soil physical properties, Soil \& Tillage Research, 80 (1-2): 233-249.

MINITAB Inc. (2007). MINITAB Statistical Software Release 15 for Windows. Minitab Inc. State College, Pennsylvania. 
Mulumba, L.N. and Lal, R. (2008). Mulching effects on selected soil physical properties, Soil \& Tillage Research, 98 (1): 106-111.

Mweso, E. (2003). Evaluating the Importance of Soil Water Availability (As a land Quality) on Selected Rainfed Crops in Serowe Area, Botswana. Available Online: http://www.itc.nl/library/Papers_2003/msc/nrm/mweso. pdf

Ojeniyi, S.O. and Adekayode, F.O. (1999). Soil conditions and cowpea and maize yield produced by tillage methods in the rainforest zone of Nigeria, Soil and Tillage Research, 51 (1): 161-164.

Olaoye, J.O. (2002). Influence of tillage on crop residue cover, soil properties and yield components of cowpea in derived savannah ectones of Nigeria, Soil \& Tillage Research, 64 (3-4):179-187.
Ozpinar, S. and Isik, A. (2004). Effects of tillage, ridging and row spacing on seedling emergence and yield of cotton, Soil \& Tillage Research, 75 (1): 19-26.

Rachman, A, Anderson, S.H., Gantzer, C.J. and Thompson, A.L. (2003). Influence of Long-term Cropping Systems on Soil Physical Properties Related to Soil Erodibility, Soil Sci. Soc. Am. J., 67:637-644.

Rasmussen, K.J. (1999). Impact of ploughless soil tillage on yield and soil quality: A Scandinavian review, Soil \& Tillage Research, 53 (1): 3-14.

Smith, M.J. (1988). Soil Mechanics, (4 ${ }^{\text {th }}$ edn.), Longman Scientific \& Technical, Essex.

Veenstra, J.J., Horwath, W.R., Mitchell, J.P. and Munk, D.S. (2006). Conservation tillage and cover cropping influence soil properties in San Joaquin Valley cottontomato crop. Available Online: http://calag.ucop.edu/0603JAS/pdfs/ConservTillageTo mato.pdf 